\title{
Bleaching and hurricane disturbances to populations of coral recruits in Belize
}

\author{
Peter J. Mumby* \\ Centre for Tropical Coastal Management Studies, Department of Marine Sciences and Coastal Management, \\ Ridley Building, University of Newcastle, Newcastle upon Tyne NE1 7RU, United Kingdom
}

\begin{abstract}
In 1998, coral populations in Belize were disturbed simultaneously by a severe coral bleaching event and Hurricane Mitch. The impact of these disturbances was assessed for naturally occurring populations of coral recruits ( 2 to $20 \mathrm{~mm}$ diameter), at a depth of 8 to $10 \mathrm{~m}$ on the forereef of Glovers Atoll. Bleaching took place at all 4 study sites but the hurricane only affected 2 sites, enabling the effects of bleaching to be compared to those arising from bleaching plus hurricane damage. Predisturbance recruit density, size-frequency distribution, and community structure were similar between sites (at kilometre scales). The bleaching event lasted ca $3.5 \mathrm{mo}$. From 70 to $90 \%$ of adult colonies bleached and at least $25 \%$ of recruits exhibited signs of bleaching. A month after adult colonies had regained usual colouration, only $1 \%$ of recruits showed even partial bleaching. Surprisingly, coral bleaching alone had no measurable effect on either recruit density or community structure. The combination of bleaching and hurricane disturbance reduced total recruit densities to $20 \%$ of pre-disturbance levels. Effects of bleaching/hurricane disturbance on community structure were spatially patchy, and I suggest that such patchiness may arise from variable cover of protective microhabitat and/or different storm conditions mediated by proximity to reef cuts (breaks in the reef crest).
\end{abstract}

KEY WORDS: Coral recruitment $\cdot$ Bleaching $\cdot$ Hurricane Mitch $\cdot$ Mortality $\cdot$ Community structure

\section{INTRODUCTION}

From September to December 1998, coral populations in Belize experienced two of the most severe disturbances of recent decades: massive coral bleaching and Hurricane Mitch. Coral bleaching refers to the paling of coral tissue brought about by a loss of coral's zooxanthellate symbionts and/or a breakdown of zooxanthellate pigments (Glynn 1993, Brown 1997). The $1997 / 8$ bleaching event in Belize was part of the most widespread bleaching event ever recorded and was probably attributable to anomalies in maximum seawater temperatures and solar irradiance (International Society for Reef Studies 1998). In late October (during the bleaching), the eye of Hurricane Mitch passed approximately $200 \mathrm{~km}$ south-east of Glovers Reef. Hurricane Mitch was a category 5 storm and was the

•E-mail: p.j-mumby@ncl.ac.uk severest hurricane event at Glovers Atoll since Hurricanes Greta in 1978 and Hattie in 1961 (see Stoddart 1963, Stoddart et al. 1982).

Here, I document the effects of bleaching and hurricane events on coral recruits occurring naturally on the forereefs at Glovers Atoll. Recruits are defined as juvenile corals at the size of first sighting in the adult habitat (Caley et al. 1996), which encompasses diameters of 2 to $20 \mathrm{~mm}$ in this study (see also Hughes 1985). Corals on the seaward side of the atoll experienced both bleaching and hurricane events, whereas populations on the leeward side were sheltered and experienced bleaching but no apparent mechanical damage from the hurricane. By surveying recruits shortly before and after these disturbance events, and on opposite sides of the atoll, I compare the impacts of bleaching with the combination of bleaching and Hurricane Mitch. As far as I am aware, this is the first study to examine the effects of bleaching and hurricanes on juvenile Caribbean corals. Specifically, I ask the following questions 
with respect to an offshore atoll in Belize: (1) Does a severe bleaching event (as defined by the degree of bleaching on adult colonies) lead to net mortality of recruits? (2) What is the net post-recruitment mortality rate arising from the combination of bleaching and Hurricane Mitch? (3) How do bleaching and 'bleaching plus hurricane' events affect the community structure of recruits?

Synergistic effects between bleaching and hurricane disturbance were not examined because no site experienced hurricane damage but no bleaching.

\section{METHODS}

Surveys were conducted at 4 sites on Glovers Atoll (Fig. 1). Sites on the seaward forereef (East 1 [E1] and East 2 [E2]) experienced bleaching and hurricane damage whereas leeward sites (West 1 [W1] and West 2 [W2]) only experienced bleaching. Sampling for recruits was conducted in late July 1998 and January 1999, which equates to ca $5 \mathrm{wk}$ before the bleaching and $4 \mathrm{wk}$ after the end of bleaching, and 3 mo before the hurricane and 2 mo after the hurricane. In situ bleaching observations were made in early October.

Recruitment was measured by the same diver visually inspecting replicate 10 by $0.5 \mathrm{~m}$ belt transects orientated parallel to the reef crest and located haphaz- ardly. Care was taken to inspect cryptic habitats (e.g. between Montastraea knobs) in which recruits were often found. Each site was located near the drop-off and was dominated by Montastraea annularis and $M$. faveolata. Sites measured approximately 60 by $30 \mathrm{~m}$ and depth ranged between 8 and $10 \mathrm{~m}$. The maximum diameter of each recruit was measured using a clear rule and species identification was made when possible. Recruits arising from asexual fragmentation of branching colonies (Hughes 1985) were ignored as were (rare) cases where larger juveniles (>20 mm diameter) of massive species had fragmented into recruitsized daughter colonies. The diameter of the smallest observable recruit was $2 \mathrm{~mm}$ but species designation was not possible, and therefore data are reported here by genus. Replication differed during pre-disturbance surveys: 2 transects were surveyed at $\mathrm{W} 2,6$ at E2, 7 at $W 1$, and 10 at E1. Sample size for post-disturbance surveys (14 transects, except W2 which had 13) was determined for a $90 \%$ power of detecting a 2-sample difference in density of 6 recruits (sample standard deviation) based on the pooled standard deviation of pre-disturbance data. Measurements of adult coral cover where made using 18 replicate $1 \mathrm{~m}^{2}$ quadrats per site.

Overall differences in recruit density were tested using a 2-factor unbalanced general linear model ANOVA (Minitab 1997) with sites and times as fixed

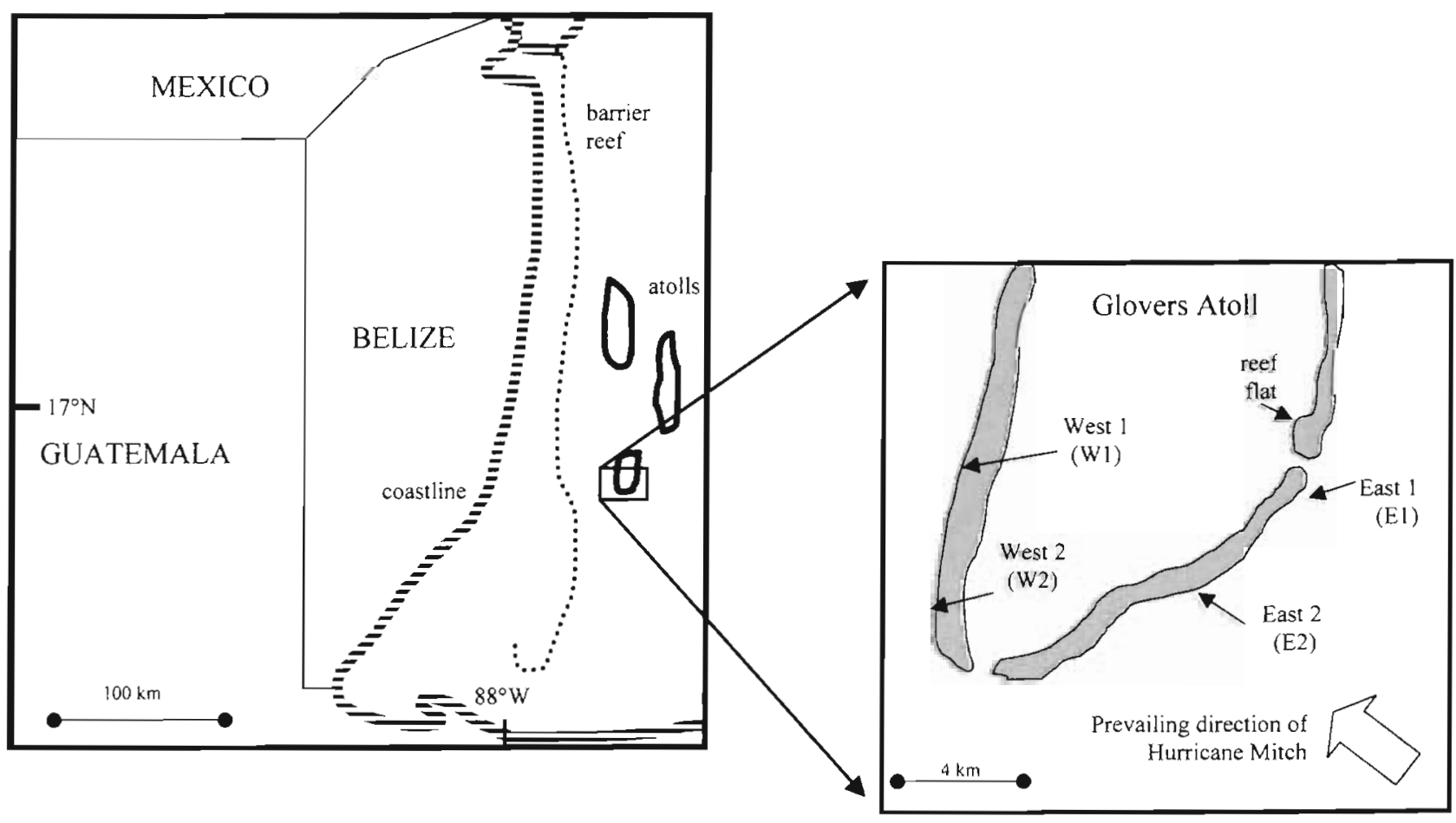

Fig. 1. Distribution of sampling sites at Glovers Atoll (= Glovers Reef) showing the location of reef cuts (breaks in the reef crest) and the path of Hurricane Mitch 
factors. Multiple comparisons were defined a priori and examined using Bonferroni tests. The size-frequency distribution of recruits was examined using 4 classes: $2-5,6-10,11-15$ and $16-20 \mathrm{~mm}$. To investigate the effects of disturbance on the structure of recruit communities at each site, community distance was measured using the Bray-Curtis similarity coefficient and represented using non-metric multidimensional scaling (MDS). The Bray-Curtis similarity coefficient has a number of desirable properties for measuring community similarities, such as ignoring joint absences of species (Mumby et al. 1996), and is a robust measure of ecological distance (Faith et al. 1987). MDS is a widely used method of presenting multivariate differences in community structure between samples in 2 dimensions (Clarke 1993). Data were averaged per site without transformation. Differences in community structure were examined using similarity percentage (SIMPER) analysis of the contribution made by each genus to mean inter-site dissimilarity (see Clarke 1993).

\section{RESULTS}

\section{GeneraI impacts of coral bleaching and Hurricane Mitch at Glovers Atoll}

The 1998 coral bleaching event began in early September following a month of calm weather and increasing water temperature (to 29 to $32^{\circ} \mathrm{C}$, depending on the site, T. J. Bright pers. comm.). Most adult corals showed recovery of colouration by late December 1998 (i.e. 3 to 4 mo later). Early signs of bleaching-induced partial mortality (large patches of recently dead tissue overgrown with filamentous algae) on adult corals at Sites $W 1$ and W2 suggested that Agaricia spp. experienced the greatest partial mortality (ca 20\%, Mumby unpubl. data). Acropora cervicornis is not common $<2 \%$ total benthic cover), and ca $20 \%$ of total colony area has died recently. Recent mortality on adult Montastraea spp. and Porites spp. was ca 10 and 5\% respectively (Mumby unpubl. data). During the bleaching event, 70 to $90 \%$ of adult colonies appeared to be either fully or partially bleached at all sites (Mumby unpubl. data, M. D. McField pers. comm.). Approximately $25 \%$ of recruits were par- tially bleached during October ( $\mathrm{n}=130$ ) but only 5 recruits (of 374 censused) were partially bleached by January 1999 and none were fully bleached (see McField 1999 for discussions of full and partial bleaching).

With $7 \mathrm{~m}$ seas for several days, Hurricane Mitch caused extensive damage to shallow reefs removing ca $90 \%$ of living Acropora palmata at some sites. Direct damage to adult corals at Sites E1 and E2 (8 to $10 \mathrm{~m}$ ) will be reported elsewhere but ca $85 \%$ of large Montastraea annularis colonies showed recent partial mortality

\section{Spatial patterns of recruitment}

Pre-disturbance densities of recruits were similar among sites (Fig. 2): ca 10 recruits per $5 \mathrm{~m}^{2}$ transect. Unbalanced ANOVA gave highly significant main effects of site and time, and site-time interactions (Table 1). Bonferroni multiple comparisons (not shown) revealed that recruit density did not vary significantly between sites before the disturbances. Overall recruitment levels after the bleaching event (at Sites W1 and (W2) were not significantly different to prebleaching levels. Significant ANOVA effects were attributable to the reduction of recruits at eastern sites following the combination of bleaching and Hurricane Mitch $(p<0.001)$ The reduction of recruitment density at eastern sites was remarkably consistent: 80 and $81 \%$ of pre-disturbance levels at Sites E1 and E2 respectively. Conversely, recruitment density showed only a $1 \%$ decrease at Site $\mathrm{W} 1$ and a $3 \%$ increase at Site W2.

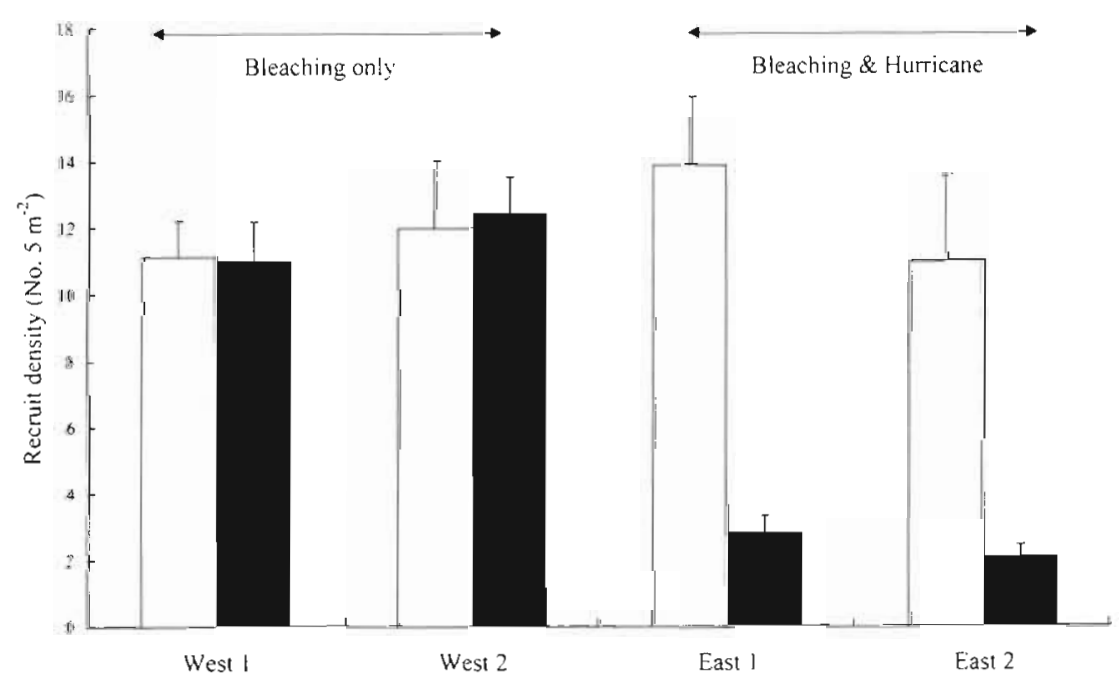

Fig. 2. Overall patterns in recruitment density for all genera. Open bars: pre-disturbance (July 1998) data, solid bars: post-disturbance (January 1999) data. Error bars standard error 

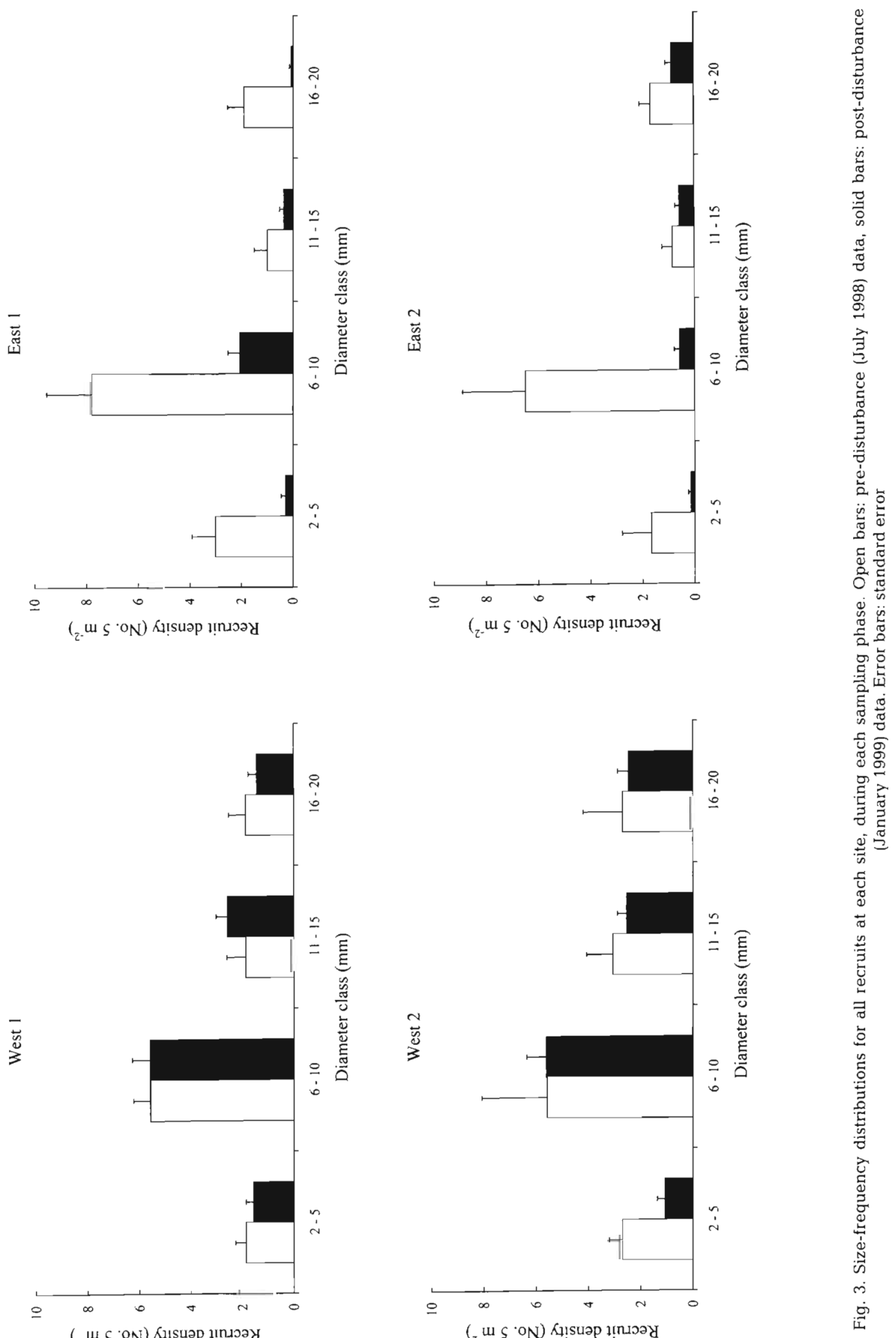
Table 1 Unbalanced general linear model ANOVA comparing recruit density between sites, sampling times, and their interaction

\begin{tabular}{|lrccrrr|}
\hline Source & df & Sequential SS & Adjusted SS & Adjusted MS & $F$ & \multicolumn{1}{c|}{ p } \\
\hline Site & 3 & 675 & 263 & 87 & 5.67 & 0.002 \\
Time & 1 & 623 & 316 & 316 & 20.42 & $<0.001$ \\
Site $\times$ Time & 3 & 413 & 413 & 127 & 8.90 & $<0.001$ \\
Error & 72 & 1116 & 1116 & 15 & & \\
Total & 79 & 2829 & & & & \\
\hline
\end{tabular}

change community structure. However, the bleaching/hurricane impacts were site-specific resulting in different communities at Sites E1 and E2 (Fig. 4, Table 2).

Table 2 shows how the combination of bleaching and hurricane affected differences in community structure between Sites E1 and E2. Before disturbance, the absolute differences in community structure were small, which is reflected in the absolute contributions of each genus to inter-site dissimilarity. Several genus-specific patterns emerge from Table 2. Populations of Agaricia did not decline in the same proportions at each site: densities were relatively high at Site E1 after disturbance. Conversely, the relative abundance of Porites was reversed after the disturbances because of higher mortality at Site E1. Stephanocoenia was a good discriminating genus before disturbance but disappeared at both sites during the combined bleaching and hurricane.

\section{DISCUSSION}

\section{Juvenile communities pre-disturbance}

Brooding coral species dominated the juvenile communities at Glovers Reef, which is consistent with all studies of juvenile communities in the Western Atlantic (Bak \& Engel 1979, Rylaarsdam 1983, Rogers et al. 1984, Smith 1992). Populations of juvenile corals are usually reported to exhibit fairly chaotic dynamics because of high rates of whole colony mortality (Hughes 1985, Hughes \& Jackson 1985, Van Moorsel 1985) and colony fragmentation. For example, Bak \& Engel (1979) reported $33 \%$ mortality in individual corals of diameter 2 to $20 \mathrm{~mm}$, over a 6 mo period in Curaçao (approximately the same depth, duration and size range of the present study). Rates of fission and fusion in juvenile corals within the size range studied here are unclear. Van Moorsel (1985) concluded that $21 \%$ of agaricid corals in the size range 3 to $46 \mathrm{~mm}$ exhibited intra- or inter-colony fission or fusion. However, fission and fusion rates for the small 2 to $20 \mathrm{~mm}$ colonies were not presented separately. Reproduction in brooding corals usually takes place at least several times a year (Szmant 1986) and planulation rate in Agaricia agaricites is greatest in spring and summer, as water temperature rises (Van Moorsel 1983). Overall, recruitment typically exhibits great variation on spatial scales ranging from within sites (Babcock 1989, Smith 1992) to adjacent reefs, regions and provinces (Hughes et al. 1999).
Fig. 4. Non-metric MDS ordination of juvenile community structure between sites and sampling periods. Stress $=0.01$
$\triangle \quad$ El pre-disturbance
- El post-disturbance
$\diamond \quad$ E2 pre-disturbance
- E2 post-disturbance 
Table 2. Differences in community structure of eastern sites, E1 and E2, before and after the combined bleaching and hurricane disturbances. Contrib.: absolute contribution of each genus to the overall dissimilarity between communities E1 and E2 in a given sampling period and sums to total dissimilarity between sites

\begin{tabular}{|c|c|c|c|c|c|c|}
\hline \multirow[t]{3}{*}{ Genus } & \multicolumn{3}{|c|}{ Pre-disturbance communities } & \multicolumn{3}{|c|}{ Post-disturbance communities } \\
\hline & \multicolumn{2}{|c|}{$\begin{array}{l}\text { Mean colony density } \\
\qquad\left(5 \mathrm{~m}^{-2}\right)\end{array}$} & \multirow[t]{2}{*}{ Contrib. } & \multicolumn{2}{|c|}{$\begin{array}{l}\text { Mean colony density } \\
\qquad\left(5 \mathrm{~m}^{-2}\right)\end{array}$} & \multirow[t]{2}{*}{ Contrib } \\
\hline & E1 & E2 & & E1 & E2 & \\
\hline Agaricia & 7.00 & 3.17 & 17 & 1.64 & 0.57 & 29 \\
\hline Ponites & 2.40 & 1.50 & 9 & 0.21 & 0.43 & 12 \\
\hline Stephanocoenia & 0.90 & 1.30 & 6 & 0.00 & 0.00 & - \\
\hline Siderastrea & 0.30 & 1.50 & 6 & 0.07 & 0.14 & 5 \\
\hline Montastraea & 0.30 & 1.00 & 4 & 0.00 & 0.07 & 1 \\
\hline Leptoseris & 1.60 & 1.67 & 4 & 0.71 & 0.50 & 17 \\
\hline Scolymia & 0.60 & 0.17 & 3 & 0.07 & 0.07 & 3 \\
\hline Madracis & 0.00 & 0.33 & 1 & 0.00 & 0.00 & 0 \\
\hline Mycetophyllia & 0.30 & 0.00 & 1 & 0.00 & 0.07 & 2 \\
\hline Colpophyllia & 0.10 & 0.00 & 0.5 & 0.07 & 0.14 & 4 \\
\hline
\end{tabular}

settlement mortality, (2) populations are not strongly recruitment limited but settlement space and post-settlement mortality are similar between sites, and (3) populations are not recruitment limited but postsettlement mortality is highly density-dependent. These explanations cannot be eliminated at present and further studies are needed to examine spatio-temporal dynamics of larval supply, settlement space, and post-settlement mortality at different sampling grains (sample unit sizes) as well as spatial distances (Caley et al. 1996, Mumby 1999).

The density, size-frequency distribution, and community structure of recruits were found to be highly consistent between sites before the bleaching and hurricane disturbances began. This was surprising considering that sites were drawn from opposite sides of Glovers Atoll and the spatio-temporal patterns of recruitment usually show great variation. The scale of the study may provide some insight into the apparent uniformity of community characteristics. Edmunds et al. (1998) described an appropriate sampling strategy for juvenile corals ( 0.4 to $5.0 \mathrm{~cm}$ diameter) to consist of seventeen $0.25 \mathrm{~m}^{2}$ quadrats placed along 4 transects (total area sampled per site is $17 \mathrm{~m}^{2}$ ). With the exception of Site W2 in summer which was poorly replicated, the total area sampled per site in this study ranged from 25 to $50 \mathrm{~m}^{2}$ pre-disturbance, and was $70 \mathrm{~m}^{2}$ post-disturbance. Further, the sample unit $\left(5 \mathrm{~m}^{2}\right)$ was 10 -fold larger than that used by Edmunds et al. (1998) and nearly 150-fold larger than that used by Smith $(1992,1997)$ in Bermuda and Florida. The size range (and therefore average density) of corals surveyed by Edmunds et al. (1998) was larger than that studied in the present study, preventing a strict comparison of methodologies, but it is clear that the sampling design had unusually large grain and extent (Wiens 1989). Such a large-scale sampling design may have averaged out small-scale chaotic population dynamics (in the absence of major disturbances) and less abundant species would have been relatively well represented. However, although a large-scale sampling design may have provided accurate and precise results, it does not fully explain the similarities in population parameters between sites. Putative explanations for the ubiquity in pattern include: (1) populations are recruitment limited and each site has similar larval supply (including brooded planulae) and post-
It is tempting to suggest that the dominance of recruits in the 6 to $10 \mathrm{~mm}$ size category may represent a large-scale early summer recruitment event. However, densities of the smallest recruits in this size class ( 2 and $3 \mathrm{~mm}$ diameter) were probably underestimated during visual sampling even though cryptic habitats were scrutinised carefully. The 2 to $5 \mathrm{~mm}$ class is probably a better record of 4 to $5 \mathrm{~mm}$ recruits. The proportion of 2 to $3 \mathrm{~mm}$ corals ranged from 0 to $4 \%$ of total recruit abundance, so undersampling had little impact on the conclusions reached by this study, although very recent $(<1 \mathrm{mo}$ ) recruitment events would have been difficult to measure.

\section{Effects of coral bleaching}

The 1998 coral bleaching episode at Glovers Atoll affected all species, ca 70 to $90 \%$ of adult colonies, and lasted for approximately $3.5 \mathrm{mo}$. Given the short time interval between recovery from bleaching and recruit surveys, and similarities in pre- and post-bleaching size-frequency distributions, community structure, and recruit density, it seems unlikely that bleaching caused high juvenile mortality rates which were then obscured by rapid post-bleaching recruitment. Thus, the results of this study suggest that net bleachinginduced mortality of coral recruits, measured ca $1 \mathrm{mo}$ after the event, was insignificant. There was significant recruitment of a spawning species (Colpophyllia natans) at 1 site between sampling intervals but since its proportional abundance was low $(<5 \%)$, C. natans recruitment did not compensate for mortality in other species in the community-level analyses.

This is the first study (to the best of my knowledge) to show the direct effects of a severe bleaching event on 
the population dynamics of juvenile corals. I suggest at least 4 possible explanations for the apparent absence of bleaching-induced mortality. Experimental tests are necessary to discriminate among them.

(1) Did juveniles experience a severe bleaching event?

Few studies of in situ bleaching (if any) have specifically examined whether juvenile corals experience similar bleaching responses to those exhibited by adult colonies. I did not conduct detailed recruitment surveys during the bleaching event but visits to each study site suggested that approximately $25 \%$ of recruits showed either partial or (occasionally) full bleaching. These observations were made a third of the way into the bleaching event and cannot be considered representative since an unknown proportion of recruits may have bleached earlier and subsequently recovered or died, or bleached later (the same is true of snapshot estimates of bleaching intensity in adult corals). It is safest to conclude that at least $25 \%$ of recruits experienced some bleaching during the event and that 1 mo after the adults had regained normal colour only $1 \%$ of recruits exhibited even partial bleaching. The difficulties of quantifying the severity of the bleaching event notwithstanding, it appears unlikely that recruits survived a bleaching event purely by avoiding becoming bleached; it is more likely that the incidence of bleaching in juvenile corals was less than that in adults. It is not clear whether reduced bleaching in juvenile corals might result from an ontogenic physiological change in zooxanthellate susceptibility to bleaching, or simply an external consequence of juvenile microhabitat (see suggestions under Question 4 below).

(2) Was bleaching-induced stress insufficient to create colony mortality?

Did bleaching stress reduce growth rates effectively shifting juveniles into a dormant state? Dormancy would help explain the consistent size-frequency distributions at Sites $\mathrm{W} 1$ and $\mathrm{W} 2$ before and after bleaching, but for population parameters to remain unchanged, chronic levels of mortality would have to be absent or balanced by recruitment and growth. Mortality rates are unlikely to be zero over 6 mo (Bak \& Engel 1979) and therefore recruitment and growth must have occurred. It is not clear whether mortality rates are simply low and balanced by low levels of recruitment and growth, or whether population sizes are tightly regulated (e.g. by density-dependent mortality) such that even a marked mortality event could have been compensated by recruitment and growth. Future studies are needed to examine population dynamics at various temporal scales and with manipulations in recruit density. Empirical studies are also needed on the effects of bleaching on juvenile growth rate, but, as I point out next, local conditions may mitigate the influence of bleaching on growth.

(3) Did heterotrophic feeding on sediments mitigate reduced autotrophic nutrition during bleaching?

The western side of Glovers Atoll experiences continual sediment deposition from the seaward lagoon (Gischler 1994). Whilst sediment can reduce the growth rate, smother and kill juvenile corals (Birkeland 1977, Hunte \& Wittenberg 1992, Babcock \& Mundy 1996), low levels of sediment may permit heterotrophic feeding on epipelic micro-organisms (Tomascik \& Sander 1987). Since the levels of suspended sediment deposition at Glovers are not high enough to deem the reef uninhabitable to juvenile corals, it is feasible (but not tested) that sedimentation levels augment the feeding and therefore survivorship of recruits on this atoll.

(4) Do juvenile corals receive less irradiance by virtue of their cryptic microhabitat?

High levels of ultraviolet and photosynthetically active radiation (PAR) have been implicated to stimulate coral bleaching (see review by Brown 1997). Whether the cryptic location of many juvenile corals on, for example, under-sides and vertical surfaces (Babcock \& Mundy 1996) confers a refuge from sustained direct exposure to irradiance remains to be seen. Furthermore, whilst some juvenile corals bleach, exposure of the (bleached) coral tissue to PAR may partly determine the fate of the coral. Studies are needed into the scattering and attenuation of irradiance at the scales of recruit microhabitat and into the direct effects of irradiance on bleached coral tissue.

\section{Effects of coral bleaching plus Hurricane Mitch}

Coral bleaching was present throughout the Belize Barrier Reef and atolls making it impossible to distinguish the effects of hurricane disturbance on bleached and non-bleached coral populations. Given the observed absence of a bleaching-induced disturbance to juvenile corals at western sites, however, it seems unlikely that bleaching would have significantly exacerbated the damage created by the hurricane. Hurri- 
cane events lead to mortality of recruits by sediment scouring, direct mechanical breakage, and the removal of substratum. Post-hurricane events such as an ephemeral bloom of blue-green and filamentous green algae (R. B. Aronson \& T. J. Bright pers. comm.) may also create further stress: Van Moorsel (1985) found filamentous algae to be the greatest cause of mortality in juvenile Agaricia humilis.

Spatially patchy responses of adult communities to hurricane damage are well established (Woodley et al. 1981, Edmunds \& Witman 1991, Witman 1992, Bythell et al. 1993a,b, Rogers 1993), and, based on this study, it appears that this premise extends to juvenile communities at a depth of 8 to $10 \mathrm{~m}$. The proportional reduction of Agaricia and Leptoseris recruits was less at Site E1 than Site E2. Site-specific mortality patterns may offer a simple explanation of the differences in relative agaricid abundance. First, survivorship of agaricid recruits may have been higher at Site E1 because the cover of Montastraea was greater at Site E1 (ca $60 \%$ vs $39 \%$ at Site E2; note cover of Montastraea is exceptionally high at these sites). Most agaricid recruits surveyed in January were found deep between Montastraea knobs, which may have provided shelter from scouring and direct mechanical stress. Second, proximity to reef cuts may affect the velocity and surge of water. Site E1 is near a reef cut whereas Site E2 is midway along a continuous reef (Fig. 1). Mechanical damage to adult colonies appeared to be more severe at Site E2, which might be because dispersal of storm surge is impaired where connectance to the lagoon is impaired by a reef crest. It is possible, but perhaps unlikely, that differences in agaricid abundance were actually attributable to (or modified by) recruitment. If agaricid planulae settled immediately after the hurricane and grew at their maximum reported linear extension rate of ca $80 \mu \mathrm{m} \mathrm{d}^{-1}$ (Van Moorsel 1985), they would have reached $6 \mathrm{~mm}$ diameter by the January census, placing them in the size class of greatest abundance at Site E1. However, it is doubtful whether maximum growth rates would have been realised. High water temperatures would have favoured high growth rates but reduced autotrophic productivity during bleaching and the abundance of fouling filamentous green algae would lower growth rate (Van Moorsel 1985).

\section{Large-scale context of results}

The absence of significant mortality in populations of coral recruits during a severe bleaching event was unexpected, especially given the sensitivity of juveniles to some other stresses (Bak \& Engel 1979). It is too early to comment on the generality of this result among
Caribbean reefs which also experienced severe bleaching. The responses of juvenile coral populations to large-scale phenomena such as coral bleaching need to be categorised. For each type of bleaching event (e.g. duration, percent of adults affected in each bleaching class), classifications should attempt to relate the physical and biological conditions of the site (e.g. depth, physical exposure, herbivore grazing intensity, adult coral cover) to the responses of juveniles at the scales of community, life history strategy, and individual populations. If patterns emerge at large spatial scales, such classifications will be instrumental in modelling the impacts of bleaching events on the dynamics of coral metapopulations (Mumby 1999) and therefore help bridge the gap between the large scale of many population processes and the often inadequate scale at which they are studied.

Acknowledgements. I would like to thank Elizabeth Glynn, Ben Hadfield, and Karen James for their assistance in the field. Dr Tom Bright, Cindy Liles, and the staff of Glovers Reef Marine Research Station provided invaluable logistical support. I thank the Belize Department of Fisheries and the Wildlife Conservation Society for permission to work at Glovers Atoty. The comments of 4 referees improved an earlier version of the manuscript. This study was funded by a NERC Fellowship under the Earth Observation Science Initiative. This is contribution number 5 of Glovers Reef Marine Research Station.

\section{LITERATURE CITED}

Babcock RC (1989) Fine-scale spatial and temporal patterns in coral settlement. Proc 6th Int Symp Coral Reef 2: $635-639$

Babcock R, Mundy C (1996) Coral recruitment: consequences of settlement choice for early growth and survivorship in two scleractinians. J Exp Mar Biol Ecol 206:179-201

Bak RPM, Engel MS (1979) Distribution, abundance and survival of juvenile hermatypic corals (scleractinia) and the importance of life history strategies in the parent coral community. Mar Biol 54:341-352

Birkeland C (1977) The importance of rate of biomass accumulation in early successional stages of benthic communities to the survival of coral recruits. Proc 3rd Int Symp Coral Reef $1: 15-21$

Brown BE (1997) Adaptations of reef corals to physical environmental stress. Adv Mar Biol 31:221-299

Bythell JC, Bythell M, Gladfelter EH (1993a) Initial results of a long-term coral reef monitoring program: impact of Hurricane Hugo at Buck Island Reef National Monument, St. Croix, US Virgin Islands. J Exp Mar Biol Ecol 172:171-183

Bythell JC, Gladfelter EH, Bythell M (1993b) Chronic and catastrophic natural mortality of three common Caribbean reef corals. Coral Reefs 12:143-152

Caley MJ, Carr MH, Hixon MA, Hughes TP, Jones GP, Menge BA (1996) Recruitment and the local dynamics of open marine populations. Annu Rev Ecol Syst 27:477-500

Clarke KR (1993) Non-parametric multivariate analyses of changes in community structure. Aust J Ecol 18:117-143 
Edmunds PJ, Witman JD (1991) Effect of hurricane Hugo on the primary framework of a reef along the south shore of St. John, US Virgin Islands. Mar Ecol Prog Ser 78:201-204

Edmunds PJ, Aronson RB, Swanson DW, Levitan DR, Precht WF (1998) Photographic versus visual census techniques for the quantification of juvenile corals. Bull Mar Sci 62:937-946

Faith DP, Minchin PR, Belbin L (1987) Compositional dissimilarity as a robust measure of ecological distance. Vegetatio 69:57-68

Gischler E (1994) Sedimentation on three Caribbean atolls Glovers Reef, Lighthouse Reef and Turneffe Islands, Belize. Facies 31:243-254

Glynn PW (1993) Coral reef bleaching: ecological perspectives. Coral Reefs 12:1-17

Hughes TP (1985) Life histories and population dynamics of early successional corals. Proc 5th Int Symp Coral Reef 5: $101-106$

Hughes TP, Jackson JBC (1985) Population dynamics and life histories of toliaceous corals. Ecol Monogr 55:141-166

Hughes TP, Baird AH, Dinsdale EA, Moltschaniwskyj NA, Pratchett MS, Tanner JE, Willis BL (1999) Patterns of recruitment and abundance of corals along the Great Barrier Reef. Nature 397:59-63

Hunte W, Wittenberg M (1992) Effects of eutrophication and sedimentation on juvenile corals: II. Settlement. Mar Biol $114: 625-631$

International Society for Reef Studies (1998) ISRS Statement on bleaching. Reef Encounter 24:19-20

McField MD (1999) Coral response during and after mass bleaching in Belize. Bull Mar Sci 64:155-172

Minitab (1997) Minitab user's guide. Minitab Inc, PA

Mumby PJ (1999) Can Caribbean coral populations be modelled at metapopulation scales? Mar Ecol Prog Ser 180: $275-288$

Mumby PJ, Clarke KR, Harborne AR (1996) Weighting species abundance estimates for marine resource assessment. Aquat Conserv Mar Freshw Ecosys 6:115-120

Rogers CS (1993) Hurricanes and coral reefs: the intermediate

Editorial responsibility: Otto Kinne (Editor),

Oldendorf/Luhe, Germany disturbance hypothesis revisited. Coral Reefs 12:127-137

Rogers CS, Fitz HC III, Gilnack M, Beets J, Hardin J (1984) Scleractinian coral recruitment patterns at Salt River Submarine Canyon, St. Croix, U.S. Virgin Islands. Coral Reefs 3:69-76

Rylaarsdam KW (1983) Life histories and abundance patterns of colonial corals on the Jamaican reefs. Mar Ecol Prog Ser 13:249-260

Smith SR (1992) Patterns of coral recruitment and post-settlement mortality on Bermuda's reefs: comparisons to the Caribbean and Pacific reefs. Am Zool 32:663-673

Smith SR (1997) Patterns of coral settlement, recruitment and juvenile mortality with depth at Conch Reef, Florida. Proc 8th Int Symp Coral Reef 2:1197-1202

Stoddart DR (1963) Effects of Hurricane Hattie on the Britısh Honduras reefs and cays, October 30-31, 1961 Atoll Res Bull No. 95

Stoddart DR, Fosberg FR, Sachet MH (1982) Ten years of change on the Giover's reef cays. Atoll Res Bull No. 257

Szmant AM (1986) Reproductive ecology of Caribbean reef corals. Coral Reefs 5:43-54

Tomascik T, Sander F (1987) Effects of eutrophication on reefbuilding corals. III. Reproduction of the reef-building coral Porites porites. Mar Biol 94:77-94

Van Moorsel GWNM (1983) Reproductive strategies in two closely related stony corals (Agaricia, Scleractinia). Mar Ecol Prog Ser 13:273-283

Van Moorsel GWNM (1985) Disturbance and growth of juvenile corals (Agaricia humilis and Agaricia agaricites, Scleractinia) in natural habitats on the reef of Curacao. Mar Ecol Prog Ser 24:99-112

Wiens JA (1989) Spatial scaling in ecology. Funct Ecol 3: 385-39?

Witman JD (1992) Physical disturbance and community structure of exposed and protected reefs: a case study from St. John, US Virgin Islands. Am Zool 32:641-654

Woodley JD and 19 others (1981) Huricane Allen's impact on Jamaican coral reefs. Science 214:749-755

Submitted: March 15, 1999; Accepted: July 16, 1999

Proofs received from author(s): November 25, 1999 